\title{
Effect of fixation on particle retention by microflagellates: underestimation of grazing rates $^{*}$
}

\author{
M. E. Sieracki ${ }^{1}$, L. W. Haas ${ }^{1}$, D. A. Caron $^{2}$ \& E. J. Lessard ${ }^{3}$ \\ ${ }^{1}$ Virginia Institute of Marine Science, School of Marine Science, College of William and Mary, \\ Gloucester Pt, Virginia 23062, USA \\ ${ }^{2}$ Woods Hole Oceanographic Institution, Woods Hole, Massachusetts 02543, USA \\ ${ }^{3}$ Horn Point Environmental Laboratory, University of Maryland, Cambridge, Maryland 21613, USA
}

\begin{abstract}
The uptake of fluorescent particles by protists and filter-feeding metazoa is being used increasingly by microbial ecologists to study feeding behavior and measure grazing rates. Recent studies of microflagellate uptake of these inert particles have yielded inconsistent results. In particular, grazing rates determined from fluorescent particle uptake are often less than rates measured using other techniques. These low uptake rates have been attributed to osmotrophy, food quality or size selection, rapid egestion of inert particles, and the slower feeding by free-living, as opposed to attached, protists. We have found that a variety of flagellates egest food vacuole contents upon fixation with several commonly used agents including glutaraldehyde and formaldehyde. During time course experiments, the observed microsphere uptake rate for a small chrysomonad flagellate using $1 \%$ glutaraldehyde was only $6 \%$ of the rate obtained by using the fixation method of van der Veer (1982) ( $2 \%$ acrolein, $2 \%$ glutaraldehyde and $1 \%$ tannic acid), modified for epifluorescence microscopy. Uptake rates of several mixed flagellate populations also were 2.4 to 3.1 times higher using the modified van der Veer method than with $1 \%$ glutaraldehyde. The average number of ingested microspheres cell ${ }^{-1}$ using this method was similar to that observed in live cells immobilized with $\mathrm{NiSO}_{4}$. Glutaraldehyde also caused the egestion of Synechococcus sp. cells and fluorescently labelled bacteria from the chrysomonad flagellate. We conclude that previous studies using common aldehyde fixation with particle uptake for measuring rates of microflagellate bacterivory have significantly underestimated actual rates of consumption, and that these studies must be re-evaluated, and perhaps repeated, using effective fixation methods.
\end{abstract}

\section{INTRODUCTION}

The importance of the microbial loop in planktonic ecosystems is now generally recognized (Sieburth 1977, Azam et al. 1983). The amount of energy flowing through the bacteria and phototrophic picoplankton $(0.2$ to $2.0 \mu \mathrm{m}$ ) (Sieburth et al. 1978) to protistan grazers, and perhaps on to larger protists and metazoa, is not accurately known, however. This uncertainty is largely due to the difficulty of accurately measuring predation rates of small protists, including flagellates and ciliates, on picoplankton.

A variety of methods have been used to determine predation rates of phagotrophic protists on bacteria and

- VIMS Contribution No. 1377; WHOI Contribution No. 6487 ; UMCEES Contribution No. 1802 phototrophic picoplankton (Hollibaugh et al. 1980, Fenchel 1982, Davis \& Sieburth 1984, Anderson \& Fenchel 1985, Lessard \& Swift 1985, Sherr et al. 1986). Direct observation of the uptake of non-fluorescing particles by ciliates can be used to estimate grazing rates (Fenchel 1980, Johnsson 1986), but ingested bacterial-sized particles are more easily detected when they are fluorescent (Børsheim 1984, Bird \& Kalff 1986, Cynar \& Sieburth 1986, McManus \& Fuhrman 1986). Several workers have used the microsphere uptake method to study size and taste selection by ciliates and metazoa (Rassoulzadegan et al. 1984, DeMott 1986, Jonsson 1986) and it appears to yield accurate predation rates for some ciliates (Børsheim 1984, Sanders \& Porter 1986, Pace \& Bailiff in press). This method, however, has yielded inconsistent and often unreasonably low rates for smaller microflagellates (Cynar \& 
Sieburth 1986, McManus \& Fuhrman 1986, Sanders \& Porter 1986, Sherr et al. 1987, Pace \& Bailiff unpubl.). Explanations for these apparent low rates for flagellates have included: (1) food selection based on quality or size (McManus \& Fuhrman 1986, Sherr et al. $1987) ;(2)$ the rapid egestion of inert particles (Cynar \& Sieburth 1986); (3) an osmotrophic rather than phagotrophic nutritional mode (Sanders \& Porter 1986); (4) that attached, rather than free-living protists, are the major predators of bacteria in nature (Cynar \& Sieburth 1986).

Observations are described here which suggest one explanation for the reported low rates of particle uptake by microflagellates. Common fixation methods caused these cells to egest their food vacuole contents. A fixation method has been found which preserves food vacuoles in flagellates and yields considerably higher ingestion rates.

\section{MATERIALS AND METHODS}

Flagellate cultures and populations. A chrysomonad microflagellate was isolated from an enrichment culture obtained from Dr. Robert J. Olson (Woods Hole Oceanographic Institution). The enrichment culture was produced by sorting phycoerythin-containing cells from a Sargasso Sea sample using a flow cytometer/cell sorter. The flagellate was sorted with phycoerythrincontaining cells presumably due to the presence of ingested cyanobacteria cells. It varied in size from 3.5 to $5.5 \mu \mathrm{m}$ in diameter (mean, $5.2 \mu \mathrm{m}$ ) and was approximately spherical in shape. The flagellate, designated Hflag', was maintained at $22^{\circ} \mathrm{C}$ on an autoclaved medium composed of $0.01 \%$ yeast extract in $0.2 \mu \mathrm{m}$ filtered York River water (FYRW), and transferred to fresh media every 2 to $3 \mathrm{wk}$.

A mixed flagellate community was obtained from a water sample from a tidal pool at low tide in a small creek tributary of the York River by rice-grain enrichment and designated 'Mud'. After $5 \mathrm{~d}$ of incubation at $22^{\circ} \mathrm{C}$ in the dark, the enrichment was filtered through a $15 \mu \mathrm{m}$ Nitex screen to remove large ciliates and a microsphere uptake experiment was conducted $2 \mathrm{~d}$ later. A diverse community of flagellates was present at that time with at least 4 dominant forms ranging in size from 5 to about $15 \mu \mathrm{m}$

Another mixed flagellate community was obtained from a 50 l continuous-flow microcosm tank containing York River water which had been enriched with ammonium and phosphate and maintained at ambient York River temperature $\left(12^{\circ} \mathrm{C}\right)$ and light conditions. Five d after a diatom bloom peaked $(>110 \mu \mathrm{g}$ chlorophyll $\mathrm{l}^{-1}$ ), a large, diverse assemblage of heterotrophic flagellates had developed, chlorophyll had declined to less than $40 \mu \mathrm{g} \mathrm{l}^{-1}$, and a microsphere uptake experiment was conducted.

Modified van der Veer fixation method. A variety of fixatives were tested for their ability to retain $0.53 \mu \mathrm{m}$ fluorescent microspheres in flagellate food vacuoles. In addition, methyl cellulose (Protoslo) (Carolina, Biological Supply Corp., Burlington, North Carolina, USA) and $\mathrm{NiSO}_{4}$ (Lee et al. 1985) in FYRW were used to immobilize flagellates, permitting the enumeration of microspheres in live cells. The fixatives tested were: (1) van der Veer's (1982), (2) glutaraldehyde, (3) formaldehyde, (4) a combination of glutaraldehyde and formaldehyde, and (5) $\mathrm{HgCl}_{2}$. We used a combination of $4 \%$ acrolein, $4 \%$ glutaraldehyde, and $2 \%$ tannic acid which van der Veer (1982) reported to give the best preservation of fine structure for light microscopy. This was added to the samples at a 50:50 dilution for final concentrations of 2,2 , and $1 \%$, respectively. Appropriate amounts of glutaraldehyde $(70 \%)$, tannic acid (both from Electron Microscopy Science, Fort Washington, Pennsylvania, USA), and acrolein (97\%) (Tousimis Research Corp., Rockville, Maryland, USA) were diluted into FYRW or artificial seawater to make the working solution. This solution was filtered through a $0.2 \mu \mathrm{m}$ filter and stored at $3^{\circ} \mathrm{C}$. Acrolein fumes are very toxic so precautions, such as working with gloves in a fume hood, are necessary (van der Veer 1982).

Since van der Veer's fixative was found to form a precipitate with the fluorochrome proflavine $(3,6$ diaminoacridine) hemisulfate (Sigma Chemical Co., St. Louis, Missouri, USA), the slide preparation procedure of Haas (1982) was modified as follows. The fixed sample (typically 0.5 to $1 \mathrm{ml}$ ) was diluted with 2 to $3 \mathrm{ml}$ FYRW, filtered at low vacuum onto a 1 or 3 um blackstained polycarbonate membrane filter (Nuclepore Corp., Pleasonton, California, USA) and then rinsed with 2 to $3 \mathrm{ml} \mathrm{FYRW.} \mathrm{Two} \mathrm{more} \mathrm{ml}$ of FYRW and the proflavine stain $\left(7 \mu \mathrm{g} \mathrm{ml}{ }^{-1}\right.$ final) were added to the filter chimney, and the stained sample filtered to dryness. The repeated rinsing not only removed the fixative, but also washed more of the non-ingested microspheres through the filter. The precipitation problem was not found with the fluorochrome 4'-6-diamidino-2. phenylindole dihydrochloride (DAPI; Sigma Chemical Co.), so these samples were filtered and then stained (5 $\mathrm{g} \mathrm{m} \mathrm{ml}^{-1}$ final) without rinsing. Prepared slides were stored frozen until they were counted, within $7 \mathrm{~d}$.

Microsphere ingestion experiments. Time course experiments were conducted by transferring an aliquot of flagellate culture, with associated bacteria, into fresh medium and incubating on an articulating shaker (100 rpm) in the dark. When the cultures were between 36 and $48 \mathrm{~h}$ old, an appropriate volume of $0.53 \mu \mathrm{m}$ diameter, 'BB' carboxylated fluorescent latex microspheres (Polysciences, Warnington, Pennsylvania, USA) were 
added to a 20 to $40 \mathrm{ml}$ sample of flagellates. These microspheres fluoresce a bright blue under ultraviolet (UV) excitation. Microspheres were added at relatively high concentrations (approximately equal to bacterial concentrations) to yield high uptake for comparisons of fixation methods. Subsamples were dispensed into test tubes containing the fixative or immobilizing agent every 3 to $10 \mathrm{~min}$ for the first hour, and then at 15 to 30 min intervals over the second hour. Samples receiving $\mathrm{NiSO}_{4}$ or Protoslo were immediately put on ice and counted within $4 \mathrm{~h}$. Counts on immobilized samples stored on ice overnight indicated no loss of ingested microspheres. Slides of the fixed samples were prepared immediately as described above, and stored frozen until counted.

Ingestion of cyanobacteria and fluorescently labelled bacteria. To test the effect of fixation on the retention of ingested particles other than inert fluorescent microspheres, time course experiments were conducted using bacteria fluorescently labelled with 5(4,6-dichlorotriazin-2-yl)-aminofluorescein (Sherr et al. 1987) and the marine cyanobacterium Synechococcus sp. DC-2 as prey. Lyophilized fluorescently labelled bacteria (FLB) were obtained courtesy of B. Sherr and prepared by diluting with $0.02 \mathrm{M} \mathrm{Na}_{4} \mathrm{~S}_{2} \mathrm{O}_{7}$ in $0.85 \%$ (w/ v) $\mathrm{NaCl}$ and sonicating to disaggregate the bacteria (Velji \& Albright 1986, Sherr et al. 1987) which fluoresce bright yellow-green under blue excitation. For the time course experiment cyanobacteria of FLB were added to yield a concentration of about $10^{6} \mathrm{ml}^{-1}$ (about $10 \%$ of the total bacteria). Subsamples were taken every $3 \mathrm{~min}$ for $15 \mathrm{~min}$ and then at longer intervals for $120 \mathrm{~min}$, fixed with $1 \%$ glutaraldehyde or van der Veer's fixative, and filtered onto $3 \mu \mathrm{m}$ Nuclepore filters as described above. The flagellates were stained with DAPI so their fluorescence would not interfere with that of ingested FLB under blue light excitation or cyanobacteria under green light excitation (see 'Microscopy' below).

Microscopy. All counting of ingested particles was done with a Zeiss Universal microscope equipped with a $100 \mathrm{~W}$ mercury lamp for epifluorescence illumination. Samples immobilized with $\mathrm{NiSO}_{4}$ or Protoslo were pipetted into depression slides and cells were located under phase contrast with a $40 \times$ Neofluar objective and the Optovar magnification changer set at $2 \times$ for a final magnification of $800 \times$. When cells were located, transmitted light was turned off and the epi-illumination shutter was opened causing prey particles to fluoresce. This method prevented bias caused by the brightly fluorescing ingested particles when searching for cells and shortened the exposure times of the live cells to the intense UV (365 nm) or blue (450 to $490 \mathrm{~nm}$ ) illumination, which was observed to cause egestion after about $30 \mathrm{~s}$
A similar searching and counting method was used for the cells preserved on black-stained filters. A $100 \times$ Neofluar objective was used with a $1.25 \times$ Optovar setting, for a final magnification of $1250 \times$. In the microsphere experiments, flagellates were located by the green fluorescence of proflavine under blue excitation and blue fluorescing ingested microspheres were counted under UV excitation. In the cyanobacteria and FLB experiments, cells were located by their DAPI fluorescence under UV excitation and ingested cells were counted under blue or green (510 to $560 \mathrm{~nm}$ ) excitation.

Particles were counted as ingested only if they were distinctly within the periphery of a flagellate cell and did not lie in the same focal plane as non-ingested background particles. The narrow focal plane of the $100 \times$ objective facilitated this discrimination. While this criterion may have caused ingested particles near the bottom of the cells' periphery to be missed, it would compensate for any particles on top of and outside the cells which may have been counted as ingested. At least 100 cells or 50 ingested particles were counted per sample, except for a chrysophyte population (Dinobryon sp.) in the microcosm experiment where 16 to 59 cells were counted per sample.

\section{RESULTS}

Following the initial observation of live Hflag cells containing large numbers of ingested microspheres, a variety of fixatives and immobilizing methods were screened for retention of microspheres and inhibition of motility (required for counting ingested microspheres) using Hflag (Table 1). The treatments which yielded the best immobilization and retention of microspheres were $50 \%$ Protoslo and $0.5 \% \mathrm{NiSO}_{4}$. These 2 treatments appeared equally effective. Lower concentrations of either did not stop motility. $\mathrm{NiSO}_{4}$ was chosen as the benchmark because it required less dilution of samples than Protoslo. Cooling the samples before fixing did not help retain ingested spheres. Formaldehyde, $\mathrm{HgCl}_{2}$, and the combination of formaldehyde and glutaraldehyde all resulted in poor microsphere retention relative to $\mathrm{NiSO}_{4}$ (Table 1). No further experiments were performed with these fixatives.

A comparison of fixation by the modified van der Veer method, 3 concentrations of giutaraldehyde, and immobilization with $0.5 \% \mathrm{NiSO}_{4}$ showed that there was considerable overlap between the $\mathrm{NiSO}_{4}$ and van der Veer methods in both the average microsphere cell $^{-1}$ (Fig, 1a) and the proportion of empty cells (Fig. 1b). An analysis of variance indicated that the average microsphere cell ${ }^{-1}$ with the van der Veer method was significantly different from the $\mathrm{NiSO}_{4}$ treatment, but 


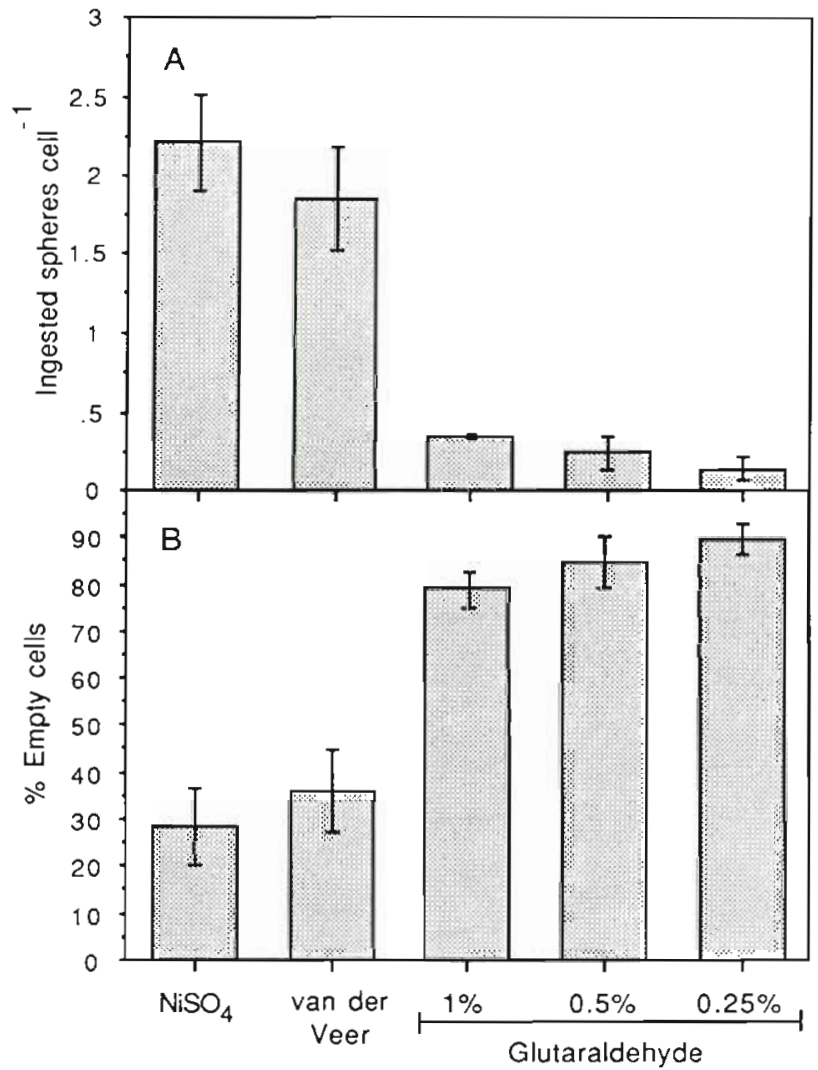

Fig. 1. Comparison of the effect of fixatives and $0.5 \% \mathrm{NiSO}_{4}$ immobilization on (A) average number of ingested microspheres per cell and (B) percent of cells with no ingested microspheres after a 1 h incubation of the chrysomonad microflagellate, Hflag, with fluorescent microspheres (diameter $=0.53 \mu \mathrm{m})$. At least 100 cells $\left(50\right.$ for $\left.\mathrm{NiSO}_{4}\right)$ were counted from each of 5 replicate samples. Error bars show standard deviations $(n=5)$

the percent of empty cells was not different $195 \%$ significance). The 3 concentrations of glutaraldehyde were similar to each other and resulted in significantly fewer microspheres cell ${ }^{-1}$ and a greater percentage of empty cells than either the $\mathrm{NiSO}_{4}$ or van der Veer treatments. Glutaraldehyde concentration appeared to
Table 1. Effect of fixation treatments on motility and retention of ingested spheres by the chrysomonad microflagellate. Hflag, cells after $60 \mathrm{~min}$ incubation with fluorescent micropheres

\begin{tabular}{|c|c|c|}
\hline Treatment $^{1}$ & Motility $^{2}$ & $\begin{array}{l}\text { Ingested } \\
\text { spheres }^{3}\end{array}$ \\
\hline Untreated cells & + & ++ \\
\hline Cooled & + & ++ \\
\hline Cooled then Form. 1\% & - & + \\
\hline Cooled then cold Glut. $0.1 \%$ & - & + \\
\hline Cooled then cold Glut. $0.3 \%$ & - & - \\
\hline Glut. $1 \%$ & - & - \\
\hline Form. $0.5 \%$ & - & + \\
\hline $5.0 \%$ & - & - \\
\hline $\mathrm{NiSO}_{4} 0.01 \%$ & + & ++ \\
\hline $0.1 \%$ & + & ++ \\
\hline $0.5 \%$ & - & ++ \\
\hline $1 \%$ Glut. \& $1 \%$ Form. & - & - \\
\hline Protoslo $10 \%$ & + & ++ \\
\hline $50 \%$ & - & ++ \\
\hline $\mathrm{HgCl}_{2} 3 \%$ & - & + \\
\hline \multicolumn{3}{|c|}{ 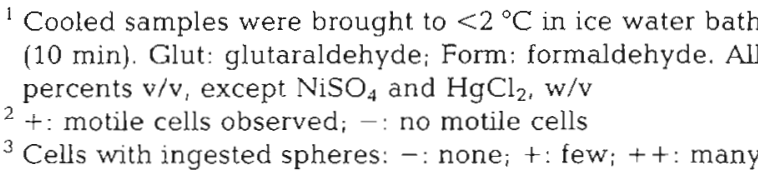 } \\
\hline
\end{tabular}

be positively correlated with average microsphere cell $^{-1}$, with the most retention of microspheres at $1 \%$ and the least at $0.25 \%$ glutaraldehyde.

The effect of fixation on the retention of ingested microspheres by 3 flagellate populations in time course experiments is shown in Fig. 2. For the Hflag monoculture (Fig. 2a) microsphere uptake was linear for the first 40 min to a maximum level about 1.6 microspheres cell ${ }^{-1}$ for both the $\mathrm{NiSO}_{4}$ and van der Veer-fixed samples. The average number of ingested microspheres cell $^{-1}$ retained by the glutaraldehyde-fixed cells, however, never exceeded 0.10 in this experiment. In both experiments with mixed populations (Fig. 2b, c) net uptake continued throughout the $2 \mathrm{~h}$ experiment,

Table 2. Comparison of microsphere uptake rates for flagellates in monoculture (Hflag), mixed enrichment culture (Mud), and 2 microscom populations. Samples were either immobilized $\left(\mathrm{NiSO}_{4}\right)$ and examined live, fixed with $1 \%$ glutaraldehyde or fixed with van der Veer's fixative

\begin{tabular}{|c|c|c|c|c|c|}
\hline \multirow{2}{*}{$\begin{array}{l}\text { Flagellate } \\
\text { population }\end{array}$} & \multirow{2}{*}{$\begin{array}{c}\mu \text { spheres } \mathrm{ml}^{-1} \\
\left(\times 10^{7}\right)\end{array}$} & \multicolumn{3}{|c|}{ Microsphere uptake cell ${ }^{-1} \mathrm{~h}^{-1}$} & \multirow{2}{*}{$\begin{array}{l}\text { Glut./van der Veer } \\
\qquad(\%)\end{array}$} \\
\hline & & $\mathrm{NiSO}_{4}$ & van der Veer & Glut. & \\
\hline Hflag & 2.34 & 2.40 & 2.3 & 0.14 & 6.1 \\
\hline Mud & 1.84 & - & 0.74 & 0.29 & 39.2 \\
\hline \multicolumn{6}{|l|}{ Microcosm } \\
\hline$I^{-}$ & 1.37 & - & 3.85 & 1.24 & 32.2 \\
\hline II $\cdots$ & 1.37 & - & 9.54 & 4.04 & 42.3 \\
\hline
\end{tabular}




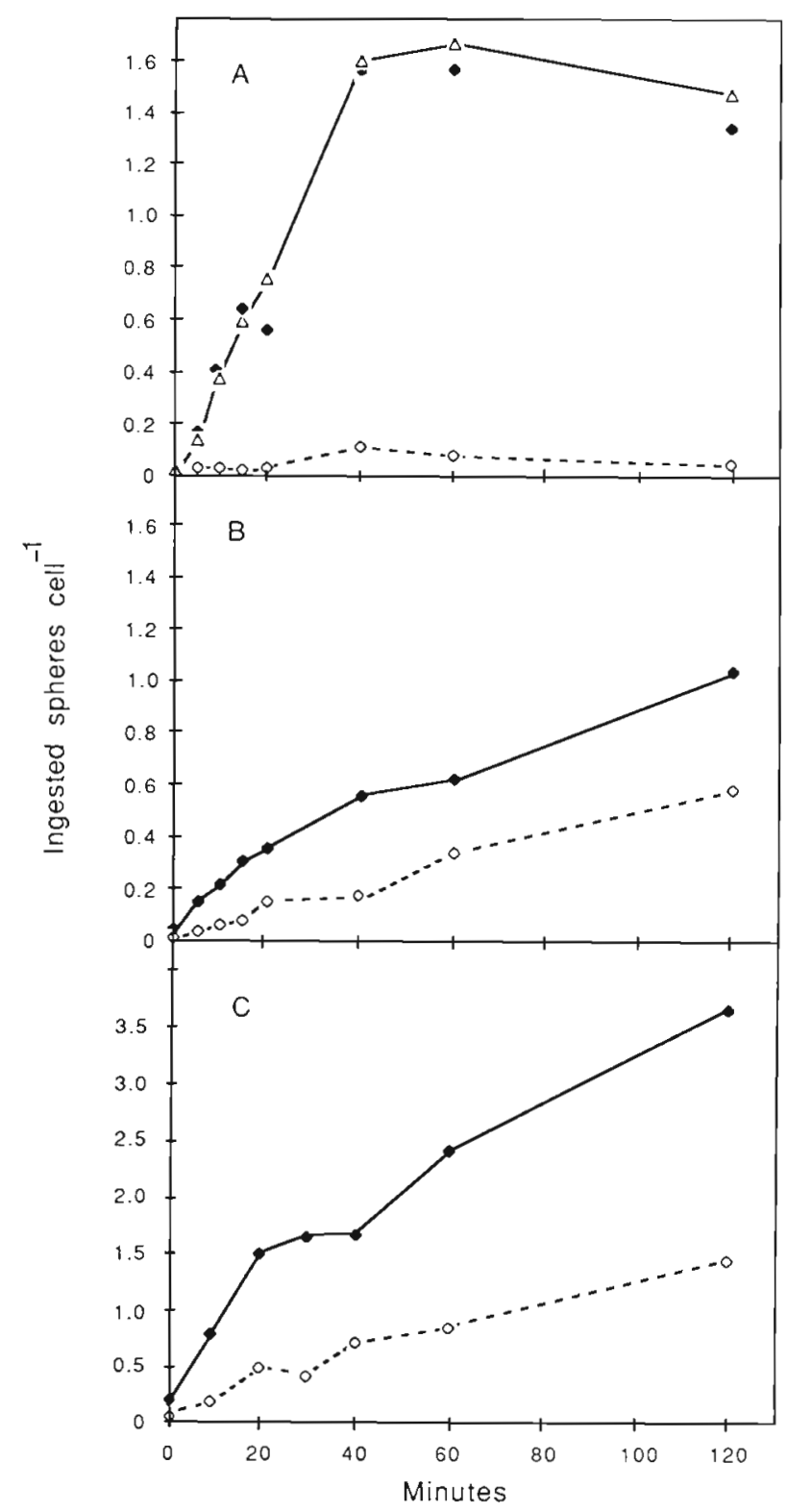

Fig. 2. Time course of fluorescent microsphere uptake by (A) a monoculture of the chrysomonad microflagellate, Hflag, and the mixed flagellate populations from (B) a rice grain enrichment (Mud), and (C) a nutrient-enriched microcosm. Samples were prepared for counting by $1 \%$ glutaraldehyde fixation $(\diamond)$, van der Veer's fixation modified for epifluorescence microscopy, ( $)$ or immobilization with $0.5 \% \mathrm{NiSO}_{4}$ for observation of live cells $(\Delta ; A)$. Note the different scale in (C)

although the initial linearity appeared to have ended by $20 \mathrm{~min}$. These populations also exhibited the emetic effect of glutaraldehyde. It appeared that larger flagellates more often retained ingested microspheres in the glutaraldehyde-fixed samples. The microcosm population (Fig. 2c) contained many choanoflagellates attached to senescing diatom chains and were the primary contributors to the high uptake rate.

Net microsphere uptake rates calculated from the glutaraldehyde-fixed samples ranged from 32 to $42 \%$ of those from van der Veer-fixed samples for microflagellate assemblages and was $6 \%$ for the singlespecies chrysomonad culture (Fig. 2; Table 2). A population of Dinobryon sp. observed in the enriched microcosm rapidly took up microspheres (time course not shown). Their microsphere ingestion rates (Table 2) were greater than any other flagellate population we observed. Within 60 min of microsphere addition many individual Dinobryon cells fixed with van der Veer's contained more than 25 microspheres and no empty cells were observed. In contrast, the maximum number of microspheres observed in a single Hflag was 12 and the proportion of empty cells was always greater than $30 \%$ of the population. The clearance rates, calculated from microsphere concentrations and uptake rates of the van der Veer-fixed samples, ranged from $0.04 \mathrm{nl}$ $\mathrm{cell}^{-1} \mathrm{~h}^{-1}$ for the Mud enrichment to $0.70 \mathrm{nl} \mathrm{cell}^{-1} \mathrm{~h}^{-1}$ for Dinobryon cells.

The average number of ingested microspheres cell ${ }^{-1}$ for all the glutaraldehyde-fixed samples from the 3 time course experiments are plotted against those from the van der Veer-fixed samples in Fig. 3. The degree of the emetic effect of glutaraldehyde is reflected in the deviation below the 1:1 line with the strongest effect in the Hflag culture, where it was first observed. The mixed populations (Mud and microcosm) showed a lesser, but significant, difference between the 2 fixation methods. Dinobryon showed the least deviation from the equivalence line (Fig. 3a).

Time course experiments of Hflag preying on either cyanobacteria or fluorescently labelled bacteria (Fig. 4 $\& 5)$ are reported in terms of the proportion of cells containing the particular fluorescing prey type since rapid digestion of these particles made enumeration of individual cells difficult, especially at later sample times. Glutaraldehyde fixation had the same effect on Hflag food vacuoles containing ingested cyanobacteria or bacteria as those containing inert microspheres. Observations of $\mathrm{NiSO}_{4}$-treated flagellates after $120 \mathrm{~min}$ incubation with cyanobacteria indicated that the duration of visible fluorescence of ingested prey ranged from $2 \mathrm{~s}$ to $3 \mathrm{~min}$. The fluorescence of non-ingested cyanobacteria in the same fields remained bright indicating that the disappearance was due to intracellular digestive processes and not solely to fading of autofluorescence.

\section{DISCUSSION}

As reviewed by Bloem et al. (1986), aldehydes at concentrations from 0.3 to $5 \%$ are the most commonly used fixatives for quantitative studies of microflagellate populations. More specifically, 0.3 to $1 \%$ unbuffered 


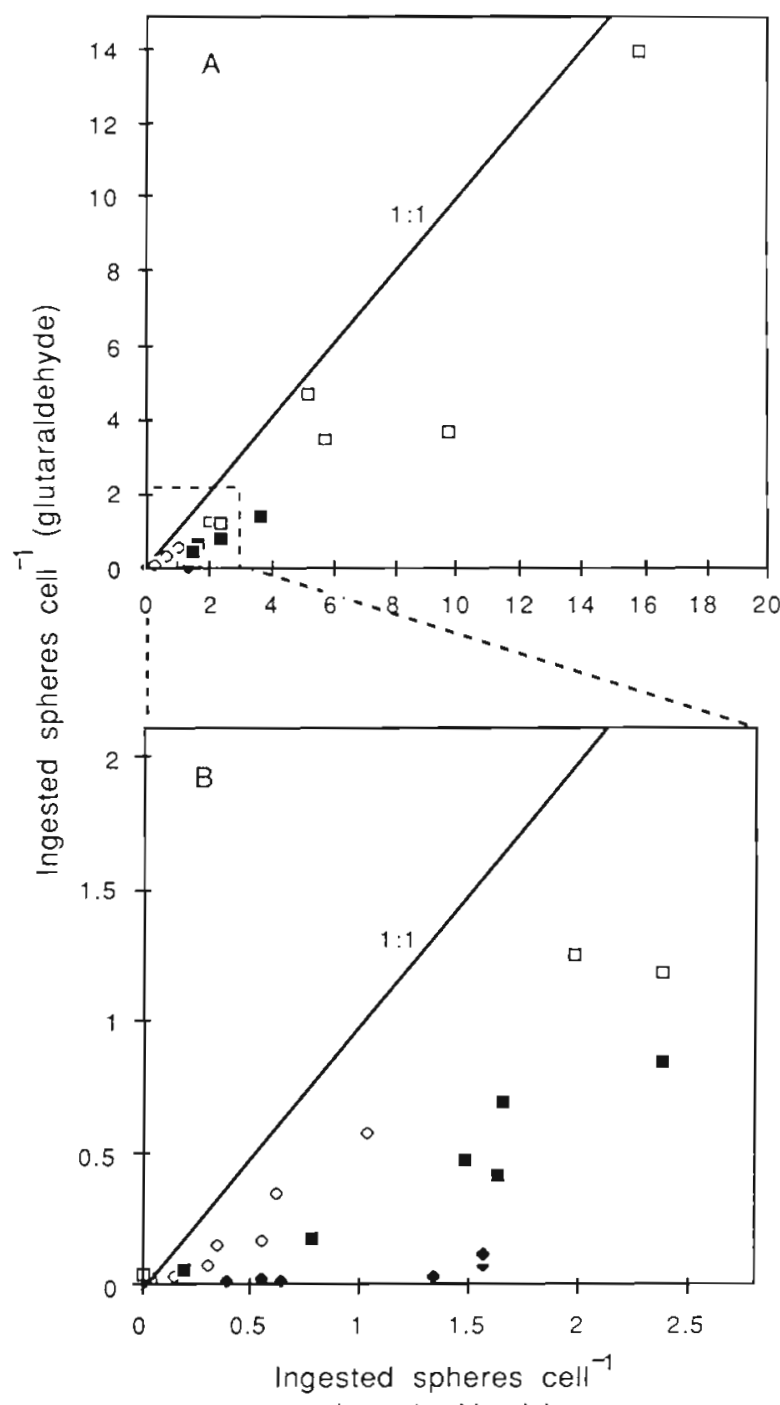

(van der Veer's)

Fig. 3. (A) Comparison between the average number of ingested microsphere cell ${ }^{-1}$ for glutaraldehyde and van der Veer's fixation for all the samples from the Hflag $(\bullet)$, Mud $(0)$, and microcosm flagellates (অ) and Dinobryon sp. (D) time course experiments. (B) Close-up of same data for average microsphere cell ${ }^{-1}$ values below 3 . The $1: 1$ line represents the equivalence of the 2 fixation methods

glutaraldehyde has become a standard fixative for epifluorescence microscopy (Bloem et al. 1986). Initial observations that glutaraldehyde caused the egestion of fluorescent microspheres by Hflag cells have been repeated with 2 populations and 2 unsorted assemblages of marine microflagellates (Fig. 2b, c). The enumeration of ingested particles in cells immobilized with $\mathrm{NiSO}_{4}$ was not ideal because cells were not preserved and samples had to be counted immediately. In addition, the method was impractical for natural samples because flagellates are not numerous enough and immobilized cells are difficult to discern from detrital

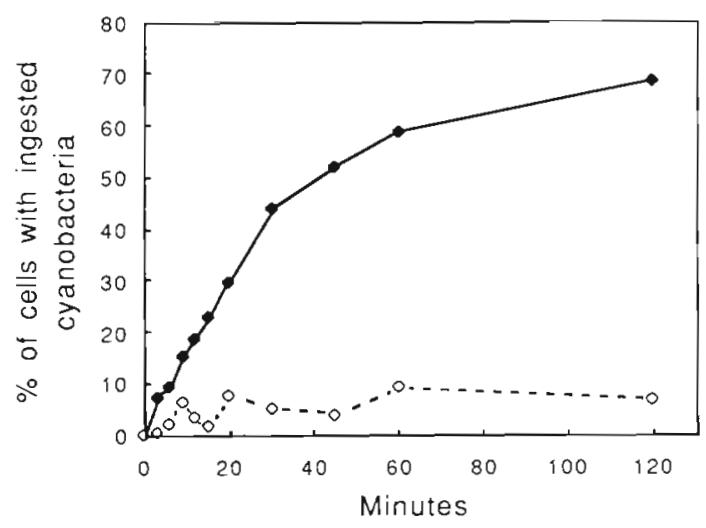

Fig. 4. Uptake by the chrysomonad, Hflag, of Synechococcus sp. (DC-2) using the modified van der Veer fixation method ( $\bullet$ or $1 \%$ glutaraldehyde fixation ( 0 ). Since cells were rapidly digested they were counted for presence or absence of ingested cyanobacteria rather than number of ingested cells

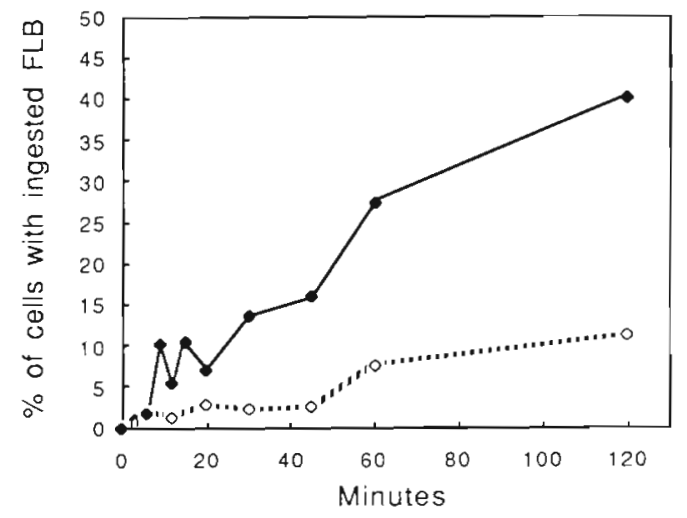

Fig. 5. Uptake of fluorescently labelled bacteria by the chrysomonad, Hflag, from samples fixed with either the modified van der Veer method $(*)$ or $1 \%$ glutaraldehyde $(0)$

particles. For these reasons we surveyed fixation techniques which would complement current epifluorescence microscopy techniques based on concentrating cells on a Nuclepore filter. Preliminary surveys indicated that various concentrations of glutaraldehyde, formaldehyde, $\mathrm{HgCl}_{2}$ and the mixture of glutaraldehyde and formaldehyde (Table 1) did not cause retention of food vacuole contents.

Van der Veer (1982) tested a range of concentrations of acrolein, glutaraldehyde and tannic acid for the best fixation of small flagellates for observation of fine structure with light microscopy. Optimal results for light microscopy $(2 \%$ acrolein, $2 \%$ glutaraldehyde, $1 \%$ tannic acid, final) also yielded the best retention of ingested particles compared to the $\mathrm{NiSO}_{4}$ treatment for the Hflag culture (Fig. 1). The modified van der Veer's technique closely matched $\mathrm{NiSO}_{4}$ immobilization across the range of average ingested microsphere cell $^{-1}$ values typically obtained from an uptake experiment (Fig. 2a). 
The emetic effect of glutaraldehyde on other flagellate populations (Fig. 2b, c) was also significant, but more variable. Even after 2 h of incubation with microspheres, very few glutaraldehyde-fixed Hflag cells contained ingested microspheres (Fig. 2a). In the other populations fixed with glutaraldehyde (Fig. 2b, c) greater uptake of microspheres was apparent. This observed uptake may explain why fixative-induced egestion has not been suspected by other investigators. Additionally, flagellates containing ingested bacteria and cyanobacteria are often observed in natural samples preserved with glutaraldehyde or formaldehyde (Haas 1982, Sherr \& Sherr 1983, Landry et al. 1984).

While the effect of glutaraldehyde may be due to physical or chemical changes in the cell or food vacuole membrane, we hypothesize that the effect is a physiological response of the cells to the chemical stress of fixation. This is supported by several lines of evidence. First, acrolein has the property of penetrating and killing cells more rapidly than other aldehydes (Hayat 1981, van der Veer 1982). Second, we observed that lower concentrations of glutaraldehyde appeared to cause more complete egestion by the population (Fig. 1). Presumably, cells would have more time to react physiologically to lower concentrations of glutaraldehyde before becoming incapacitated. Thirdly, exposure of live, immobilized cells to UV light under the epifluorescence microscope for more than 30 or $40 \mathrm{~s}$ caused the egestion of microspheres before the cells became visibly damaged. Egestion of food vacuole contents may be part of a general cellular stress response. We cannot know for sure, with the experiments performed here, whether the benchmark method $\left(\mathrm{NiSO}_{4}\right.$ and cold) caused any food vacuole egestion. Results using this method, however, were identical to $50 \%$ Protoslo, the least stressful treatment, suggesting complete, or nearly complete, retention.

Our observations on a variety of species indicate that, in addition to maintaining the integrity of food vacuoles, the van der Veer fixation method, modified for epifluorescence microscopy, is a better fixative for retaining the size and morphology of flagellates. Less shrinkage and rounding of cells was observed than with glutaraldehyde. For this reason it may be the preferred method for standard examination of flagellates by epifluorescence microscopy. We did not, however, rigorously test the accuracy of this fixative for quantitatively preserving protist populations as has been done for other, more common fixatives (Bloem et al. 1986).

Dinobryon sp. cells did not apparently egest microspheres upon exposure to glutaraldehyde to the extent of other flagellates (Fig. 3a). This may be due both to their larger cell size, and to the presence of a silicate lorica. Microspheres egested from the cell may have been retained in the lorica and, depending on orientation, could be difficult to define as egested.

Glutaraldehyde caused the egestion of not only latex microspheres but also cyanobacteria and fluorescently labelled bacteria from microflagellate food vacuoles. Methods to measure flagellate grazing rates based on the uptake of these cells must take into account the proper fixation method. The digestion of cyanobacteria caused ingested fluorescence to disappear within several minutes. Since the exact time of ingestion was not known the best estimate of digestion time is the maximum time ingested fluorescence persisted (i.e. 3 min). It is likely that the FLB are also rapidly digested, although we did not attempt to estimate this. Digestion could cause an underestimation of uptake rates of these prey items if ingested cells are enumerated after digestion has begun.

Based on the microsphere uptake rates observed in this study (Table 2) we have shown that glutaraldehyde fixation caused an underestimation of grazing rate of 58 to $68 \%$ for the mixed assemblages and $94 \%$ for the chrysomonad culture. In light of present results, recent studies using glutaraldehyde fixation which have found low or insignificant uptake of microspheres by both cultured and natural microflagellate populations (Cynar \& Sieburth 1986, McManus \& Fuhrman 1986, Sherr et al. 1987) should be re-evaluated.

Our microflagellate clearance rates are not as high as some reported values (Fenchel 1982, Davis \& Sieburth 1984, Caron et al. 1985, Bird \& Kalff 1986, Sherr et al. 1986). There are a variety of possible reasons for this. Because the bacterial density in the Hflag culture was high (mean, $2 \times 10^{7} \mathrm{ml}^{-1}$ ) and clearance rate varies inversely with prey density, we might expect lower clearance rates in these experiments. In the mixed populations (Mud and Microcosm) a substantial portion of the flagellates did not take up microspheres. It appeared that some morphological types were not taking up microspheres and that particular types were responsible for most of the uptake. Other than the Dinobryon population, we did not attempt to differentiate these types and the high proportion of empty cells was, therefore, included in the uptake calculations. Even in the Hflag monoculture there was a wide variation in the microsphere uptake rate depending on the age and growth conditions of the culture. These observations point to further work necessary to understand the feeding ecology of microflagellates.

It is still uncertain whether flagellates can select food particles on the basis of taste or size (Dubowsky 1974, Andersson et al. 1986, Sibbald et al. 1987). With the ability to attach substances such as amino acids to the surface of fluorescent microspheres (Rassoulzadegan et al. 1984, DeMott 1986) and the fixation method described here, further work can be done to test the 
taste and size selectivity of microflagellates. We believe that the fluorescent microsphere uptake method remains a useful tool for further studies of the feeding physiology and ecology of flagellates including discerning factors which control rates of bacterivory, possible temporal and spatial variation in flagellate bacterivory and identifying the primary bacterial consumers in different planktonic habitats.

Acknowledgements. We thank Dr K. L. Webb for constructive criticism of the manuscript, and P. Eldridge and D. Booth for laboratory assistance. We are grateful to Dr R. J. Olson who provided the initial enrichment culture of Hflag and Dr B. F. Sherr who provided the lyophilized FLB. This work was partially supported by the Biological Oceanography division of the National Science Foundation grants \#OCE-8316613 to L. W. H., \#OCE-8600510 to D.A.C. and \#OCE-8617565 to E.J.L.

\section{LITERATURE CITED}

Anderson, P., Fenchel, T. (1985). Bacterivory by microheterotrophic flagellates in seawater samples. Limnol. Oceangr 30: 198-202

Andersson, A., Larsson, U., Hagstrom, §. (1986). Size-selective grazing by a microflagellate on pelagic bacteria. Mar. Ecol. Prog. Ser. 33: 51-57

Azam, F., Fenchel, T., Field, J. G., Meyer-Reil, L. A., Thingstad, F. (1983). The ecological role of water-column microbes in the sea. Mar. Ecol. Prog. Ser. 10: 257-263

Bird, D. F., Kalff, J. (1986). Bacterial grazing by planktonic lake algae. Science 231: 493-495

Bloem, J., Bar-Gilisen, M. B., Cappenberg, T. E. (1986). Fixation, counting, and manipulation of heterotrophic nanoflagellates. Appl. environ. Microbiol. 52: 1266-1272

Borsheim, K. Y (1984). Clearance rates of bacteria-sized particles by freshwater ciliates, measured with monodisperse fluorescent latex beads. Oecologia (Berl.) 63: 286-288

Caron, D. A., Goldman, J. C., Andersen, O. K., Dennett, M. R. (1985). Nutrient cycling in a microflagellate food chain: II. Population dynamics and carbon cycling. Mar. Ecol. Prog. Ser. 24: 243-254

Cynar, F. J., Sieburth, J. McN. (1986). Unambiguous detection and improved quantification of phagotrophy in apochlorotic nanoflagellates using fluorescent microspheres and concomitant phase contrast and epifluorescence microscopy. Mar. Ecol. Prog. Ser. 32: 61-70

Davis, P. G., Sieburth, J. McN. (1984). Estuarine and oceanic microflagellate predation of actively growing bacteria: estimation by frequency of dividing-divided bacteria. Mar. Ecol. Prog. Ser 19: 237-246

DeMott, W. R. (1986). The role of taste in food selection by freshwater zooplankton. Oecologia (Berl.) 69: 334-340

Dubowsky, N. (1974). Selectivity of ingestion and digestion in the chrysomonad flagellate Ochromonas malhamensis. J. Protozool. 21: 295-298

Fenchel, T (1980). Suspension feeding in ciliated protozoa: functional response and particle size selection. Microb. Ecol. 6: 1-11

Fenchel, T (1982). Ecology of heterotrophic microflagellates. II. Bioenergetics and growth. Mar. Ecol. Prog. Ser. 8: 225-231

Haas, L. W (1982). Improved epifluorescence microscopy for observing planktonic microorganisms. Ann. Inst. Oceanogr. 58 (Suppl.): 261-266
Hayat, M. A. (1981). Fixation for electron microscopy. Academic Press, New York

Hollibaugh, J. T., Fuhrman, J. A., Azam, F. (1980). Radioactive labelling of natural assemblages of bacterioplankton for use in trophic studies. Limnol. Oceanogr 25: 172-181

Jonsson, P. R. (1986). Particle size selection, feeding rates and growth dynamics of marine planktonic oligotrichous ciliates (Ciliophora: Oligotrichina). Mar. Ecol. Prog. Ser. 33: $265-277$

Landry, M. R., Haas, L. W., Fagerness, V. L. (1984). Dynamics of microbial plankton communities: experiments in Kaneohe Bay, Hawaii. Mar. Ecol. Prog. Ser. 16: 127-133

Lee, J. J., Small, E. B., Lynn, D. H., Bovee, E. C. (1985). Some techniques for collecting, cultivating and observing protozoa. In: Lee, J. J., Hutner, S. H., Bovee, E. C. (ed.) An illustrated guide to the Protozoa. Soc. of Protozool., Lawrence, Kansas, p. 1-7

Lessard, E. J., Swift, E. (1985). Species-specific grazing rates of heterotrophic dinoflagellates in oceanic waters measured with a dual-label radioisotope technique. Mar. Biol 87: $289-296$

McManus, G. B., Fuhrman, J. A. (1986). Bacterivory in seawater studied with the use of inert fluorescent particles. Limnol. Oceanogr. 31:420-426

Rassoulzadegan, F., Fenaux, L., Strathman, R. R. (1984). Effect of flavor and size on selection of food by suspensionfeeding plutei. Limnol. Oceanogr. 29: 357-361

Sanders, R. W., Porter, K. G. (1986). Use of metabolic inhibitors to estimate protozooplankton grazing and bacterial production in a monomictic eutrophic lake with an anaerobic hypolimnion. Appl. environ. Microbiol. 52: 101-107

Sherr, B. F., Sherr, E. B. (1983). Double-staining epifluorescence technique to assess frequency of dividing cells and bacterivory in natural populations of heterotrophic microprotozoa. Appl environ. Microbiol. 46: 1388-1398

Sherr, B. F., Sherr, E. B., Andrew, T L., Falion, R. D., Newell, S. Y. (1986). Trophic interactions between heterotrophic protozoa and bacterioplankton in estuarine water analyzed with selective metabolic inhibitors. Mar. Ecol. Prog. Ser. 32: 169-179

Sherr, B. F., Sherr, E. B., Fallon, R. D. (1987). Use of monodispersed, fluorescently labeled bacteria to estimate in situ protozoan bacterivory. Appl. environ. Microbiol. 53: 958-965

Sibbald, M. J., Albright, L. J., Sibbald, P. R. (1986). Chemosensory response of a heterotrophic microflagellate to bacteria and several nitrogen compounds. Mar. Ecol. Prog. Ser. 36: 201-204

Sieburth, J. McN. (1977). Biomass and productivity of microorganisms in planktonic ecosystems. Helgoländer wiss. Meeresunters. 30: 697-704

Sieburth, J. McN., Smetacek, V., Lenz, J. (1978). Pelagic ecosystem structure: heterotrophic compartments of the plankton and their relationship to plankton size structure. Limnol. Oceanogr. 23: 1256-1.263

van der Veer, J. (1982). Simple and reliable methods for the fixation, mounting and staining of small and delicate marine plankton for light microscopic identification. Mar. Biol. 66: 9-14

Velji, M. I., Albright, L. J. (1986). Microscopic enumeration of attached marine bacteria of seawater, marine sediment, fecal matter, and kelp blade samples following pyrophosphate and ultrasound treatments. Can. J. Microbiol. 32: $121-126$ 